\title{
Ammatillinen koulutus työntekijäkansalaisuuden rakentajana
}

\author{
Kristiina Brunila, Katariina Hakala, Elina Lahelma \& Antti Teittinen (toim.) (2013). \\ Ammatillinen koulutus ja yhteiskunnalliset eronteot. Helsinki: Gaudeamus. 305 s. \\ ISBN 978-952-495-279-8
}

Koulutuksen voi ajatella olevan kansallinen projekti, jonka avulla kasvatetaan tulevia kansalaisia. Ammatillisen koulutuksen ja työelämän välinen kytkös on vahva, joten onkin luontevaa, että Ammatillinen koulutus ja yhteiskunnalliset eronteot on valinnut työntekijäkansalaisuuden rakentumisen tulokulmakseen ammatilliseen koulutukseen.

Teos tarkastelee työntekijäkansalaisuuden rakentumista työelämään ja koulutuspolitiikkaan vaikuttavien yleisempien yhteiskunnallisten muutosten kontekstissa. Erityisen huomion kohteena on uusliberalistinen markkinataloutta ja yksilöllistä kilpailua korostava koulutuspuhe ja sen kytkeytyminen yhteiskunnallisiin erontekoihin ja eriarvoisuuteen.
Kirjan toimittajat ja kirjoittajat työskentelevät erilaisissa tutkimustehtävissä pääasiassa Helsingin yliopiston Käyttäytymistieteiden laitoksella tai Kehitysvammaliitossa. Heitä yhdistää kriittinen yhteiskuntatieteellinen näkökulma koulutuksen tutkimukseen.

\section{ULOSSULKEMISEN KÄYTÄNTÖJÄ}

Teos jakautuu viiteen osaan. Ensimmäisessä, Ammatillisen koulutuksen paikannus, toimittajat avaavat kirjan teoreettisia ja metodologisia näkökulmia. Avainkäsitteitä ovat työntekijäkansalaisuus ja yhteiskunnalliset eronteot.

Työntekijäkansalaisuus viittaa statukseen, joka saavutetaan työelämään ja työyhteiskuntaan osallistumisen kautta. Eronteoissa on kyse siitä, miten ihmisten väliset erot, kuten yhteiskuntaluokka, sukupuoli tai vammaisuus, rakentuvat ja kuinka ne rakennetaan perusteeksi erilaiselle arvostukselle ja kohtelulle.

Käsitteiden rinnakkainen tarkastelu piirtää ammatillisesta koulutuksesta ja ylipäätään suomalaisesta, tasa-arvoiseksi oletetusta koulutusjärjestelmästä toisenlaisen kuvan kuin minkä olemme tottuneet näkemään julkisessa koulutuspuheessa. Ammatillinen koulutus ja siinä rakentuva työntekijäkansalaisuus sisältävät monia ulossulkemisen käytäntöjä, jotka voivat syventää erontekoja ja eriarvoisuutta.

\section{TIETÄMINEN VÄLINEELLISTYY}

Kirjan toisessa osassa, Tieto, taito ja tasa-arvo koulutusmarkkinoilla, 
pohditaan, mitä seuraa, kun ammatillisen koulutuksen tavoitteena on tuottaa hyviä työntekijäkansalaisia työelämän tarpeisiin.

Leila Pehkosen mukaan sivistykselle ei enää tahdo löytyä sijaa ja samalla sille annetaan näpertelyn ja hyödyttömyyden leima. Ammattiosaamisen näyttöjä tarkasteleva Ulpukka IsopahkalaBouret tuo esiin toisen seurauksen: tieto ja tietäminen välineellistyvät ja niiden käyttöarvo ja sovellettavuus korostuvat.

Suoraan yksilöihin kohdistuva seuraus on, että ammatillisen koulutuksen tavoitteissa keskitytään yhä enemmän yksilön henkilökohtaisiin ominaisuuksiin ja oikeanlaiseen asenteeseen tavoitteena muokata työelämän tarpeisiin soveltuvaa persoonallisuutta. Samalla oma tiedonhalu ohjataan tiukasti työelämän asettamille vaatimuksille alisteiseksi.

Elina Ikävalko kiteyttääkin, että tulevan työntekijäkansalaisen ihanne on "vastuullinen ja sopeutumiskykyinen subjekti, joka ei kuitenkaan ole asettumassa ajamaan yhteiskunnallisia muutoksia" (s. 84).

\section{KUKA TÄYTTÄÄ TYÖNTEKIJÄKANSALAISEN} IDEAALIN?

Teoksen kolmas osa, Ammattialojen segregaatio ja työllistymisen esteet, keskittyy ammatillisessa koulutuksessa näyttäytyviin erontekoihin: sukupuoleen, luokkaan, seksuaalisuuteen ja etnisyyteen.

Kolme ensimmäistä lukua tuottavat kiinnostavan kuvan ammatillisesta koulutuksesta monenlaisten yhteiskunnallisten erontekojen tuottajana, uusintajana ja toisinaan purkajanakin. Eroja tarkastellaan erillään, vaikka käytännössä ne usein kietoutuvat yhteen: esimerkiksi luokka-asema ja sen muotoutuminen on myös sukupuolittunut ilmiö. Erillinen tarkastelu mahdollistaa kuitenkin erontekojen ja eriarvoisuuden moninaisuuden näkyväksi tekemisen. Samalla käy ilmeiseksi, että myös tasa-arvon edistäminen edellyttää monenlaisia toimia.

Eroja käsittelevien artikkelien yhtymäkohta löytyy suhteesta työntekijäkansalaisuuteen. Uusliberalistiseen koulutuspolitiikkaan ei sovi ajatus yksilöiden epätasaarvoisista lähtökohdista, vaan kaikilla oletetaan olevan yhtäläiset mahdollisuudet tehdä valintoja vapailla koulutusmarkkinoilla. Tällöin ne, jotka eivät osaa tai joilla ei ole mahdollisuutta valita, käsitteellistyvät herkästi epäonnistujiksi, kuten Sanna Aaltonen ja Sirpa Lappalainen kirjoittavat.

Tämä jättää kuitenkin avoimen kysymyksen, jota oikeastaan kukaan teoksen kirjoittajista ei käsittele: kuka täyttää työntekijäkansalaisen ideaalin - keitä ovat ne, joilla on täydet mahdollisuudet tehdä valintoja?
Erontekojen ohella olisi tärkeää tarkastella sitä, mihin suhteutettuna erontekoja rakennetaan. Onko työntekijäkansalaisen ideaali kaikille saavuttamaton, vai voivatko tietyin resurssein varustetut yksilöt tuon ihanteen täyttää, ja mitä nuo resurssit ovat?

\section{ERILLISET KOULUTUSPOLUT VAHVISTAVAT TOISEUTTA}

Neljännen osan, Elinikäinen koulutus ja yhteiskunnan "ulkopuoli": toiseus markkinoilla, artikkelit tarkastelevat työntekijäkansalaisuuden portinvartiointia. Kohteena ovat esimerkiksi vammaiset ja rikostaustaiset nuoret, joiden peruskoulun jälkeinen koulutukseen valikoituminen ja usein myös palkkatyöhön työllistyminen nähdään tavalla tai toisella ongelmalliseksi.

Inkluusion eli mukaan ottamisen käsite yhdistää luvun artikkeleita: vaikka koulutusjärjestelmäämme kuuluva inkluusioideologia asettaa ihanteeksi opetusjärjestelyt, joissa opetus pyritään järjestämään mahdollisimman tavanomaiseksi riippumatta oppilaiden sosiaalisista eroista, ovat erityisoppilaiden koulutuspolut käytännössä erillisiä ja vahvistavat erottelua entisestään.

Kristiina Brunila tuo artikkelissaan esiin myös sen, miten yhteiskunnalliset ongelmat käännetään yksilöiden ongelmiksi. Ratkaisuksi tarjotaan yksilön mielentilan muokkaamista joustavaksi ja omaan keskeneräisyyteensä alis- 
tuvaksi ja näin työmarkkinoiden tarpeita palvelevaksi.

\section{RISTIRIITAISUUS LISÄISI KIINNOSTAVUUTTA}

Kirjan viides ja viimeinen osio on epilogi, joka sisältää toimittajien kirjoittaman yhteenvedon. Luku ei aivan lunasta lupaustaan kehittää eteenpäin työntekijäkansalaisuuteen ja erontekoihin liittyvää analyysiä, sillä se ei tuo juurikaan uutta aiempiin kirjassa käytyihin keskusteluihin.

Teoksen keskeinen sanoma kuitenkin kirkastuu: markkinoituneessa (ammatillisen) koulutuksen ilmapiirissä ei oteta riittävästi huomioon työntekijäkansalaisuudesta syrjäyttäviä tilanteita.

Teoreettisten ja metodologisten valintojen osalta teoksen artikkelit toistavat hieman itseään. Uusliberalismin käsite ja subjektifikaation prosessien tarkastelu ovat relevantteja valintoja, mutta odotin artikkelikokoelmalta hieman laajempaa käsitteellistä valikoimaa. Yhtenäinen lähestymistapa mahdollistaa vuoropuhelun artikkelien välillä, mutta ei keskustelun tarvitsisi olla niin yksimielistä.

Myös erilaisten lähestymistapojen tuomat mahdolliset ristiriitaisuudet ja säröt olisivat kiinnostavia. Lisäksi vastarinnan paikat ja toisin tekemisen tavat jäivät valitettavan pieneen rooliin.
Ammatillinen koulutus ja yhteiskunnalliset eronteot on tärkeä ja kriittinen puheenvuoro ammatillisen koulutuksen ja laajemmin uusliberalistisen koulutuspolitiikan tuottamasta eriarvoisuudesta. Artikkelit tuovat ansiokkaasti esiin sekä ammatillisen koulutuksen että yhteiskunnallisten erontekojen moninaisuuden, usein juuri niiden näkökulmasta, joiden arkeen eronteot eniten vaikuttavat.

Tekstit muodostavat artikkelikokoelmaksi harvinaisen yhtenäisen kokonaisuuden, ja artikkelit keskustelevat hyvin keskenään.

Teoksen tarjoama näkökulma työntekijäkansalaisuuteen antaa vastauksia myös koulutusta koskevaan ikuisuuskysymykseen: miksi tasa-arvoisista koulutusmahdollisuuksista huolimatta sosiaaliset asemat usein periytyvät.

Hanna Ylöstalo

YTT, aikuiskasvatuksen yliopistonlehtori Kasvatustieteiden yksikkö Tampereen yliopisto 